\title{
Spermathecal morphology and sperm dynamics in the female Schizocosa malitiosa (Araneae: Lycosidae)
}

\author{
Gonzalo USETA ${ }^{1}$, Bernhard A. HUBER ${ }^{2}$ and Fernando G. COSTA ${ }^{1}$ \\ ${ }^{1}$ Laboratorio de Etología, Ecología \& Evolución, Instituto Clemente Estable, Av. Italia 3318, 11600 Montevideo, Uruguay; \\ e-mails: gonzak@gmail.com, fgc@iibce.edu.uy \\ ${ }^{2}$ Zoologisches Forschungsmuseum Alexander Koenig, Adenauerallee 160, 53113 Bonn, Germany; \\ e-mail: b.huber.zfmk@uni-bonn.de
}

Key words. Genital morphology, spermathecae design, sperm dynamics, reproductive strategies, wolf spiders

\begin{abstract}
The linkage between spermathecal morphology and sperm dynamics was experimentally analysed in Schizocosa malitiosa (Tullgren, 1905) using histological serial sections and SEM. We recognised three connected sections for each spermatheca: basal atrium, stalk and head. The head ends blindly, is sclerotized, provided with few large pores, and surrounded by thick, presumably glandular epithelium. The atrium is also sclerotized, and connects with both copulatory and fertilization ducts, lying close to each other. A porous plate is located in the stalk-atrium connection. Nine adult females were fixed in eight reproductive conditions for reconstructing sperm dynamics: virgin, immediately after mating, one day after mating, three days after mating, one day after remating without oviposition (first male with a single useful palp, second male normal), immediately before oviposition, three days after oviposition, and one day after remating with oviposition (female had eaten first egg-sac and had remated). Our results suggest female control of sperm transport because the penetration of encapsulated sperm into the spermathecal head continues after mating. Stored sperm is maintained in an encapsulated condition until oviposition, when sperm is totally activated. Sperm cells may remain viable for a long time in the decapsulated state. There was evidence for sperm mixing in the female that remated after ovipositi on.
\end{abstract}

\section{INTRODUCTION}

Female genitalia are widely studied in arachnological research, especially in relation to taxonomy and systematics. The structures involved are frequently sclerotized and species-specific, being both easy to study and useful to identify taxa. Studies on the gross and fine structure of female spider genitalia have allowed a better understanding of male palp and female epigynum as complementary structures in copula (e.g., Grasshoff, 1968; Van Helsdingen, 1970; Huber, 1994, 1995a, b; Eberhard \& Huber, 1998). However, the precise morphology and function of chambers, ducts, and pores of the female genital tract have rarely been described in detail. The dynamics of sperm and the functions of particular structures generally remain obscure. Interest in these aspects of spider morphology strongly increased when Austad (1984) linked female genital morphology and reproductive tactics in spiders. He considered two basic types of spider spermathecae: cul-de-sac and conduit. In the first, female receptacles end blindly and sperm enters and exits by the same duct. In the second, sperm enters through a copulatory duct but exits through another duct, the fertilization duct. According to Austad, these two types of genitalia determine two different mating tactics: the culde-sac morphology favours the last male because the last sperm to enter is the first to exit the spermatheca, whereas the conduit morphology favours the first male, whose sperm is the first to reach the fertilization duct. However, a number of factors (e.g., proximity of ducts, sperm mixing) may complicate the situation, resulting in high inter- specific variability of sperm priority values and a less clear-cut division than envisaged by Austad (Eberhard et al., 1993; Elgar, 1998; Uhl, 1994, 2002). Nevertheless, Austad's inspiring paper has set the stage for the development of integrative views on functional morphology and reproductive biology.

Earlier studies on basic aspects of spider sperm dynamics include those by Harm (1931), Cooke (1966), Lamoral (1973), Serna de Esteban (1976), Forster (1980), and Higgins (1989), but some of these do not consider the female (e.g., Harm, 1931; Lamoral, 1973), and recent advances are few and scattered. Some haplogyne spiders such as Pholcus phalangioides (Fuesslin, 1775) seem to retain sperm by using viscid fluids (Uhl, 1993a, b, 1994). Others have been suggested to manipulate sperm in the spermathecae [Uhl, 2000 on Dysdera erythrina (Walckenaer, 1802), Dysderidae; Burger et al., 2003 on Opopaea fosuma, Burger, 2002, Oonopidae]. In entelegyne spiders, sperm can be stored for a long time in the female receptacles, and it is probably moved by female secretions. Glands associated with the receptacles absorb substances from and release substances into the spermathecal lumen, thus determining sperm transport (Cooke, 1966; Lopez, 1987). Several authors have stressed the presence of such glands and secretions associated with the sperm inside the female receptacle (Kovoor, 1981; Lopez, 1987), and their possible relationship with aspects of sperm nutrition, transport and activation (Suhm \& Alberti, 1996; Uhl, 1996; Berendonck \& Greven, 2005). Recent studies on the tetrablemmid spider Indicoblemma lannaianum Burger, 2005, have shown that sperm in this species is sur- 
TABLE 1. List of experimental females of Schizocosa malitiosa, detailing the main results about sperm conditions and dynamics.

\begin{tabular}{|c|c|c|c|c|}
\hline \multirow{3}{*}{ Female condition when fixed } & \multicolumn{4}{|c|}{ Sperm } \\
\hline & \multicolumn{2}{|c|}{ Atrium/Stalk } & \multicolumn{2}{|r|}{ Head } \\
\hline & Repletion & Condition & Repletion & Condition \\
\hline$A-$ virgin & - & - & - & - \\
\hline $\mathrm{B}$ - immediately after mating & Filled & Encapsulated & Penetrating & Encapsulated \\
\hline $\mathrm{C}-24 \mathrm{~h}$ after mating & Filled & Encapsulated & Filled & Encapsulated \\
\hline $\mathrm{D}$ - three days after mating & Filled & Encapsulated & Filled & Encapsulated \\
\hline $\begin{array}{l}\mathrm{E} \text { - mated first with a male with one useful palp, } \\
\text { remated with a normal male and immediately fixed }\end{array}$ & Filled & Encapsulated & Filled & Encapsulated \\
\hline $\mathrm{F}$ - just before oviposition (two females) & Filled & Decapsulated & Partially filled & Decapsulated \\
\hline $\mathrm{G}-$ three days after oviposition & Filled & Decapsulated & Filled & Decapsulated, recoiled? \\
\hline $\begin{array}{l}\mathrm{H} \text { - mated, ate the first egg sac, remated with } \\
\text { another male and fixed one day later }\end{array}$ & Filled & $\begin{array}{l}\text { Encapsulated and } \\
\text { decapsulated }\end{array}$ & Filled & $\begin{array}{c}\text { Encapsulated and } \\
\text { decapsulated, destroyed? }\end{array}$ \\
\hline
\end{tabular}

rounded by secretions produced by the female inside the spermathecae, avoiding the mixture of sperm from different males. Females of this species may have near total control of paternity, largely eliminating the options for sperm competition (Burger et al., 2006). In general, spider sperm is transported from the spermathecae to the oviduct during oviposition (Foelix, 1996). The occurrence of so-called primary (simple) pores in the head of the spermathecal wall permits secretion of glandular products into the lumen, thus displacing sperm towards the fertilization duct (Kovoor, 1981; Coyle et al., 1983; Lopez \& Juberthie-Jupeau, 1983; Bennett, 1992; Suhm \& Alberti, 1996). These pores may also permit the transport of nutritional and activating substances towards the stored sperm cells, and they probably absorb spermathecal secretions during or after copulation, allowing the flow of the sperm into the receptacle (Cooke, 1966; Lopez, 1987). Mechanical sperm transport (by spermathecal muscles and elastic cuticle) has been suggested by Michalik et al. (2005) for the mygalomorph spider Antrodiaetus unicolor (Hentz, 1842).

Spider sperm cells are transferred from the male to the female in a coiled and encapsulated state. They may remain in this state until first oviposition (Foelix, 1996) or be decapsulated shortly after insemination (Brown, 1985; Eberhard \& Huber, 1998; Berendonck \& Greven, 2005). Encysted sperm is easily activated by adding water to a fresh sperm droplet (Bösenberg, 1905; cited by Foelix, 1996) and sperm cells move using their flagellum. Before oviposition, sperm cells are decapsulated (capacitated or activated), and they actively or passively move until meeting the egg cells in the uterus externus or in the egg sac itself (Foelix, 1996). It is usually assumed that encapsulation of sperm increases persistence in time, avoiding energy costs. Data about the persistence of viable sperm in spiders is frequently anecdotal, but they can persist for up to five years in the araneid Paraplectanoides crassipes Keyserling, 1886 according to Hickman (1975).

Schizocosa malitiosa (Tullgren, 1905) is a medium to large-sized South American wolf spider. Its reproductive biology has been intensively studied in Uruguay: court- ship and mating (Costa, 1975, 1979), progeny (Capocasale et al., 1984; Costa \& Capocasale, 1985) and phenology (Costa, 1991). Copulation is complex and consists of approximately 300 palpal insertions during $90 \mathrm{~min}$ (Costa, 1979). Sperm cells of $S$. malitiosa remain viable within the female receptacles for up to over nine months (F. Costa \& G. Useta, unpubl. data), and females may generate up to four successful consecutive egg sacs after a single mating (Capocasale et al., 1984), which is comparable to other spiders (Uhl, 1993b; Huber, 1998). With the female genitalia being reduced to a "black box", our understanding of several aspects of the reproductive biology of this species has been constrained, hindering the comprehension and prediction of reproductive behaviours, tactics and strategies. The aim of this paper is to provide the basic outline of events within the female internal genitalia. Our study is limited by sample size and methodology, but it suggests potentially fruitful directions for future research involving larger sample sizes of specific reproductive phases, transmission electron microscopy, differential staining, etc.

\section{MATERIAL AND METHODS}

Nineteen female specimens were collected in Marindia, Canelones, Uruguay, between July 2002 and January 2003. Ten females were captured as adults and fixed in ethanol $75 \%$. Genitalia of these females were dissected and cleaned, first mechanically and then with sodium hydroxide 5\%, until soft tissues were dissolved. Some receptacles were transversally cut with a sharp razor blade in order to observe their internal surface. Genitalia were examined with a JEOL 5900 low vacuum scanning electron microscope.

Nine other females were collected as penultimate subadults and kept under laboratory conditions until adulthood. Seven females were allowed to mate once, the other two females mated twice. For histological sections, females were killed mechanically, immediately fixed in Bouin for $24 \mathrm{~h}$, and then transferred to ethanol $70 \%$. Later, their genitalia were included in ERL-4206 epoxy resin and serially sectioned with a diamond knife on a Microm HM 350 rotation microtome obtaining sections of 1.0 to $1.5 \mu \mathrm{m}$ thickness. Sections were stained with a mixture of azur II (1\%) and methylene blue $(1 \%)$ in an aqueous borax solution $(1 \%)$ at about $70^{\circ} \mathrm{C}$ for about $30 \mathrm{sec}$. Sections were examined under a light microscope (Olympus, BX61 with 

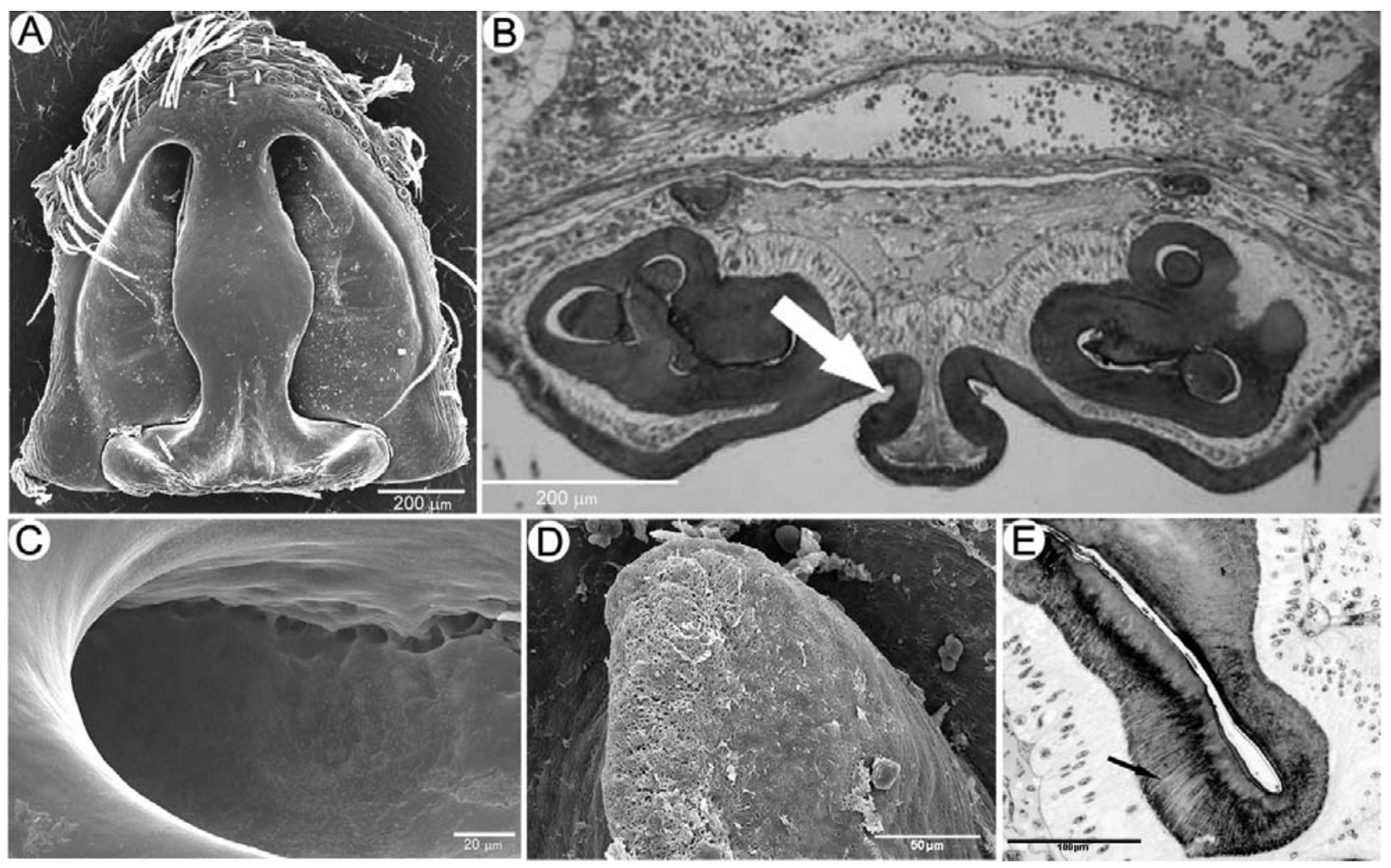

Fig. 1. A - external face (SEM) of the epigynum of Schizocosa malitiosa. B - transversal histological section of the female genitalia, showing the atria, the fertilization ducts connecting to the uterus, and the wide external face of the septum which narrows dorsally. This "stalk" (arrow) is wider frontally and thinner posteriorly. C - SEM image of the anterior third of septum, showing a furrow located in the concavity of the septum near the hood. The furrow seems to be partitioned resembling a series of consecutive holes. D - internal side (SEM) of a hood showing the spongy zone. E - histological section showing the striations of the cuticle associated to the spongy zone shown in D.

DP70 digital camera). The nine females were fixed at different moments, according to the eight conditions listed in Table 1. The first male which copulated with female E was obtained by experimentally attaching the left palp to the spider carapace with a thin string and melted paraffin following Rovner \& Wright (1975). All matings followed the typical pattern and duration of the species (Costa, 1979). The moment of oviposition of females $\mathrm{F}$ was estimated from the construction of the basal silk plate.

\section{RESULTS}

\section{Epigynum}

The genital plate (epigynum) of $S$. malitiosa is a hard sclerotized structure, roughly triangular in shape, characterized by a large median septum which is broadest posteriorly, resembling an inverted $\mathrm{T}$ (Fig. 1A). Two longitudinal concavities or pockets connect with the copulatory openings. The ventral face of the septum is relatively wide, but it becomes narrow dorsally (see transversal section of septum, Fig. 1B), generating two sagittal grooves (channels) which connect the hoods with the genital openings. At the interior side of each groove we observed a furrow that runs from the anterior third of the septum until the hood (Fig. 1C). This furrow seems to be partitioned, resembling a series of consecutive holes.

Histological sections show a thick epithelium associated with the entire internal face of the epigynum. This epithelium is most prominent in the area of the hoods. The internal face of the cuticle that corresponds to the hoods is porous or spongy (Fig. 1D). In a few sections, we observed a fine striation across this cuticle (Fig. 1E), possibly connecting the epithelium with the exterior through the furrow shown in Fig. 1C.

\section{Spermathecae}

Fig. 2A shows the internal side of the genitalia with the two spermathecae. For descriptive purposes, these can be divided into three sections that are all provided with thick and highly sclerotized walls: the head, the neck or stalk, and the basal atrium. Head and stalk are oriented forward and parallel to the abdominal wall. The head is spherical and presents evenly distributed large pores on all of its surface (Fig. 2B). The stalk is a cylindrical duct without pores. It bends at a right angle when connecting to the atrium. The atrium is voluminous and complex, presents two lobes and connects with both the copulatory and the fertilization ducts. Anteriorly, near the stalk connection, it is provided with a dense field of pores (Fig. 2C).

The internal views of the head and stalk regions show an extremely smooth surface, with only a few large pores in the head (Fig. 2D). The internal surface of the atrium is largely irregular but smooth. More sculptured surfaces were observed in the area where the atrium connects with 

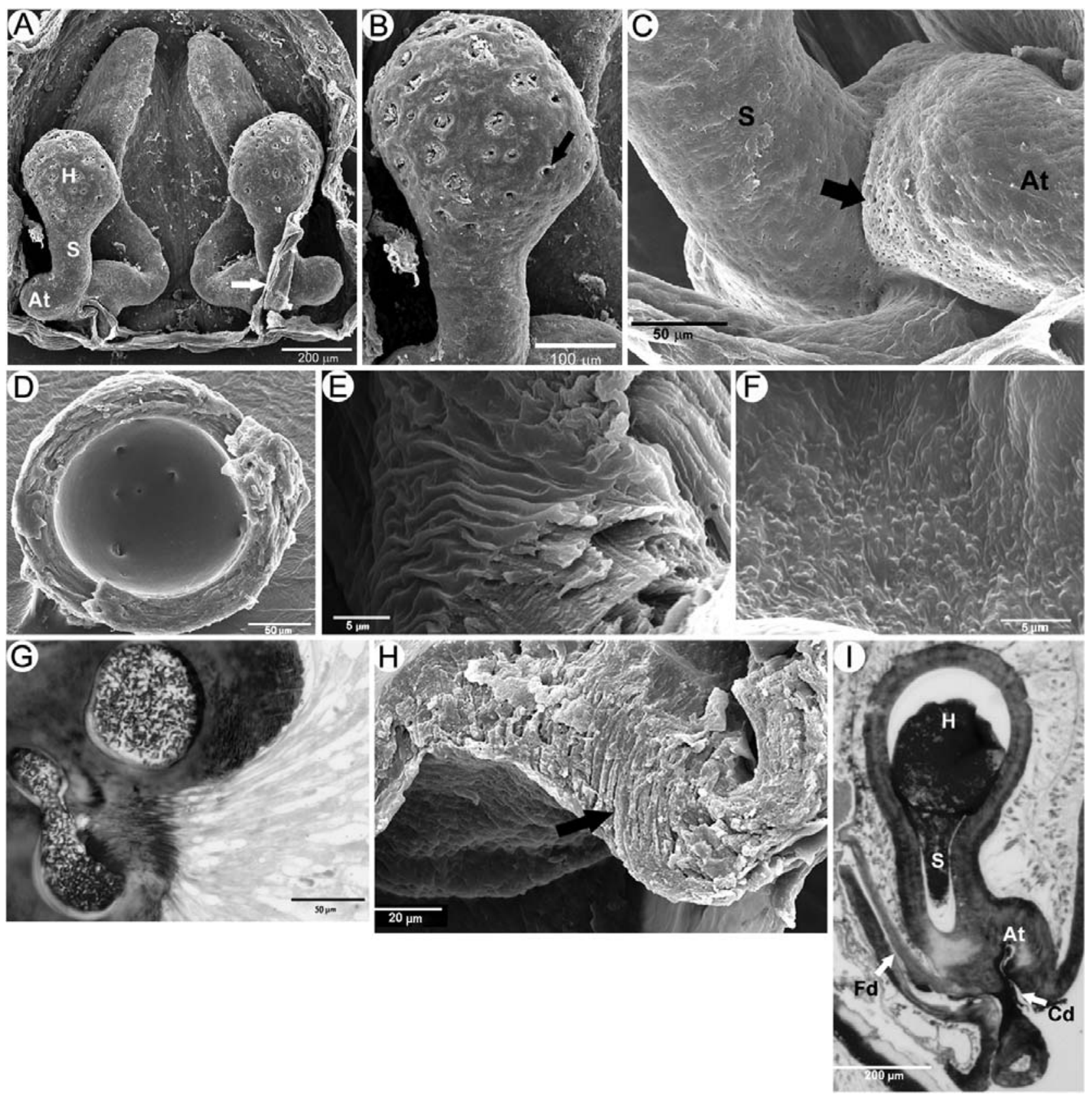

Fig. 2. (A) SEM image of the entire internal view of the genitalia, showing heads, stalks and atria of spermathecae, as well as the sclerotized portion of the fertilization duct (arrow). (B) Spermathecal head (SEM), showing large pores. (C) External view (SEM) of the stalk-atrium connection, showing the porous plate (arrow). (D) Internal view of spermathecal head (SEM) showing the very smooth surface and few large pores. (E) Internal view of the spermathecal atrium (SEM) showing smooth crumples and scale-like structures, distributed in parallel lines. The sperm sacs were cut with a razor blade. (F) Internal view of the spermathecal atrium (SEM) showing cuspules. (G) Longitudinal histological section of the spermathecal cuticle at the stalk-atrium connection, showing a set of parallel curved lines which externally connect with the porous plate. See also the sperm masses inside the stalk (above) and the atrium (below). (H) SEM image of the set of parallel curved lines shown in Fig. 2 (G), showing the tubular aspect of these structures (arrow). Note the thick wall of the spermathecae in this zone. (I) Longitudinal histological section of spermatheca, showing both the copulatory and fertilization ducts leading into the atrium lumen. $\mathrm{H}$ - head; $\mathrm{S}$ - stalk; At - atrium; Fd - fertilization duct; Cd - copulatory duct.

the stalk (Fig. 2E) and in the internal face of the atrium (Fig. 2F), but no pores were observed in these areas.

The histological sections show a thick, presumably glandular epithelium associated with the spermathecae, being particularly thick on the head. The atrium seems to be divided into two chambers, connected to each other by a buttonhole-like opening. A dense set of parallel curved lines cross the anterior wall of the atrium near the connection with the stalk. Based on light microscopy we tend to interpret these lines as ducts that connect externally with the field of pores mentioned above (Fig. 2G). SEM images show cylindrical tubules in both longitudinal as 


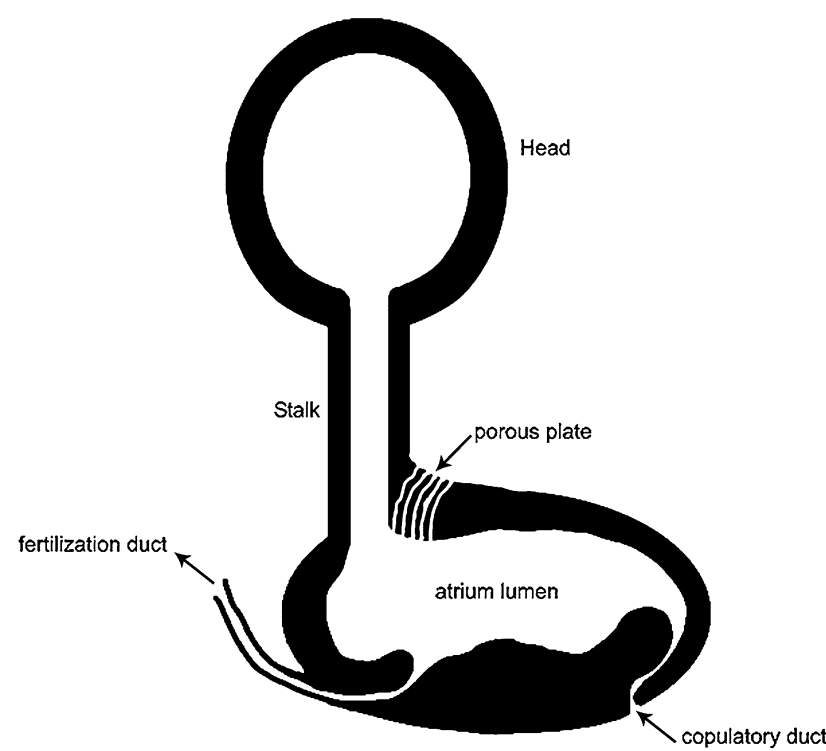

Fig. 3. Shematic representation of the main connections among sacs and ducts in the inner genitalia of female Schizocosa malitiosa.

well as transversal views (Fig. $2 \mathrm{H}$ ). The atrium wall here is very thick $(\sim 40 \mu \mathrm{m})$ compared to the other walls $(\sim 15$ $\mu \mathrm{m})$. In the ventral area of the atrium cavity, both the copulatory and the fertilization ducts connect with the atrium lumen, very close to each other (Fig. 2I). The copulatory duct is short, with a sclerotized wall and narrow lumen $(8-9 \mu \mathrm{m})$. The fertilization duct is also sclerotized where it emerges from the atrium, but then continues towards the uterus externus with a thin, nonsclerotized wall. Near the connection of the fertilization ducts to the uterus externus, we observed a layer of muscular tissue. Fig. 3 represents schematic reconstruction of the spermathecal structure.

\section{Sperm dynamics}

Immediately after copulation (female B, Table 1), sperm and secretions filled the spermathecal lumen in the atrium and stalk. One spermathecal head was filled with sperm diluted by secretions. The other head showed a central column of sperm surrounded by abundant secretions (Fig. 4A). These secretions are not distinguishable from the secretions observed in the spermathecal heads of virgin female A. Each sperm cell is individually encapsulated (cleistospermia), with a cyst diameter of 2-3 $\mu \mathrm{m}$. Females fixed one day and three days after mating (females $\mathrm{C}$ and D) both had their spermathecae completely filled with encapsulated sperm (Fig. 4B). The spermathecae contents from the female mated first with a male with only one free palp and later with a normal male (female E), showed no differences (stratification or other) between the two sides and presented the same appearance described for females $\mathrm{C}$ and D. Finally, females fixed immediately before oviposition (F) showed decapsulated sperm cells in the entire spermatheca (including in the fertilization duct), but secretions were clearly observable only in the head (Fig. 4C). Surprisingly, one spermatheca from one of these females was filled only with secretions
- similar to the virgin female - in head and stalk, but decapsulated sperm cells were present in the atrium.

Three days after oviposition (female G), all sperm remained decapsulated and present in atrium, stalk and head, but some sperm cells seemed to be recoiled (Fig. 4D). However, in female $H$, which had remated after eating her first egg sac, conditions in right and left spermathecae differed. In the right receptacle, we found only encapsulated sperm cells in the atrium (Fig. 4E), a mixture of encapsulated and decapsulated cells in the stalk, and decapsulated and partly apparently destroyed sperm in the head. In the left receptacle, there was only decapsulated sperm in the atrium, but partial mixing in the head (few apparently encapsulated cells among a majority of decapsulated cells) (Fig. 4F). In this female, the left spermathecal head content showed zones of different density, resulting from aggregations of encapsulated sperm cells embedded in secretions coloured as in female B, and some secretion droplets coloured as in the virgin female (A) secretions. We found no evidence for recapsulation.

\section{DISCUSSION}

The genitalia of $S$. malitiosa are, in general terms, typical for a lycosid (Järvi, 1908; Osterloh, 1922; Sierwald, 1989; Suhm \& Alberti, 1996), in both external (epigynum) and internal (spermathecae) views. Previous descriptions on fine morphology and dynamics of sperm storage are scarce in lycosids. Osterloh (1922) analysed the structure of the female genitalia of Pardosa amentata (Clerck, 1757) using histological sections, and Suhm \& Alberti (1996) studied the genitalia of Pardosa lugubris (Walckenaer, 1802) by both sections and SEM techniques. Here, we will discuss first the external and then the internal features found in S. malitiosa.

\section{The frontal hoods: multifunctional structures?}

The frontal hoods observed in S. malitiosa present putative glandular structures in both internal and external views: thick epithelium, spongy zone, striated cuticle and grooves. The hoods presumably allow the male to anchor an apophysis of the palpal tegulum. Both Osterloh (1922) and Sadana (1972) described and illustrated such palpal structures anchored into the females hoods in two other wolf spider species. We hypothesise that the female hood secretions in $S$. malitiosa could also be associated with communication during copula. Kovoor (1981) suggested that certain female genital glands might release sexual pheromones. Copulating $S$. malitiosa males regularly perform chewing-like movements on the recently used palp, and this behaviour could transport female secretions (i.e., pheromones) to the male mouthparts for chemical perception (Aisenberg \& Costa, 2005). The fact that males chew the palp after (and not before) insertion suggests a communicatory rather than a lubricant function.

\section{Female control of sperm transport}

The entire design of the spermathecal ducts and chambers in $S$. malitiosa suggests that the spermathecae function like a cul-de-sac rather than like a conduit system (sensu Austad, 1984). The copulatory and fertilization 

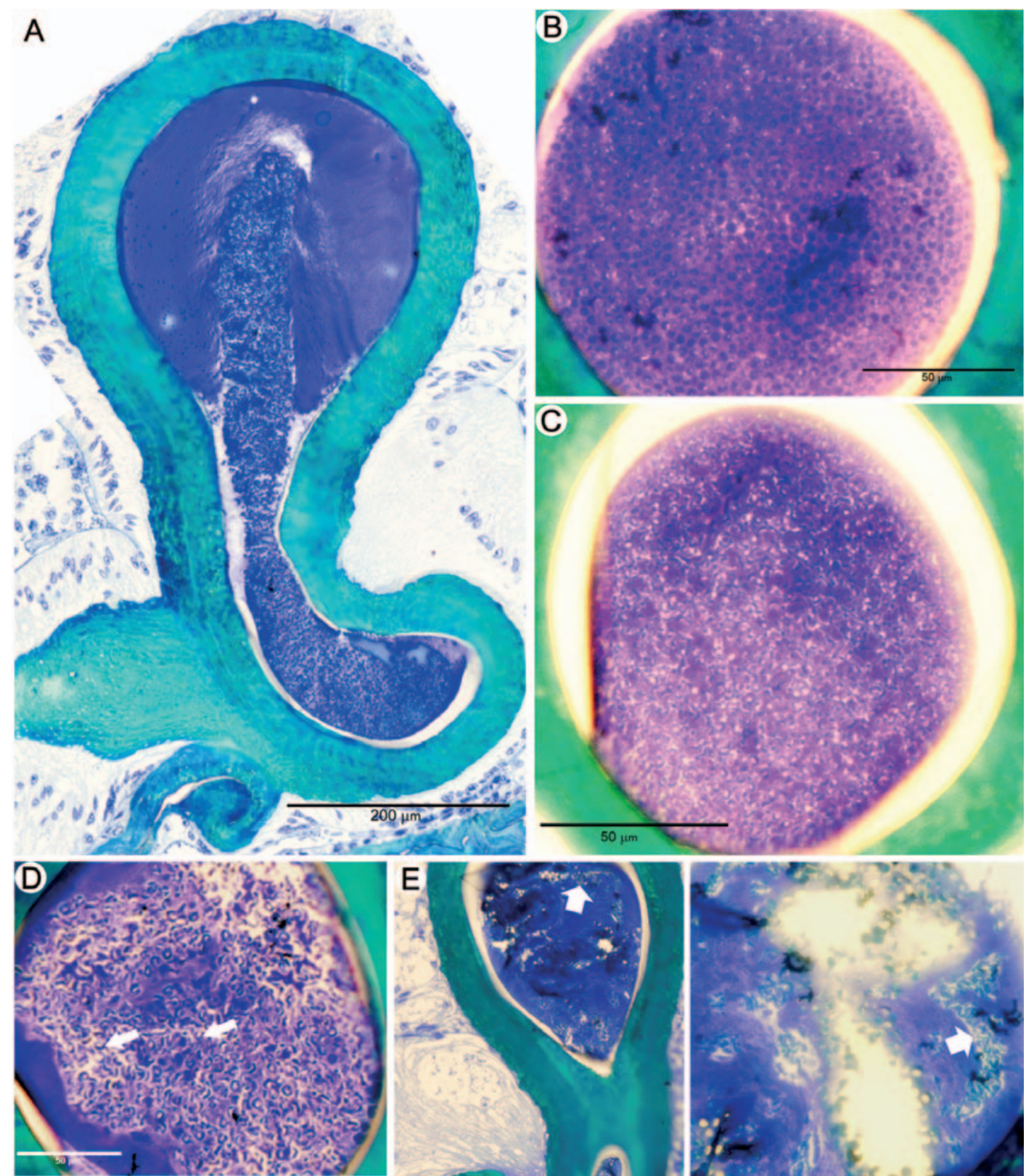
ducts connect to the atrium close to each other. The large pores in the head presumably release and absorb secretions, as has been suggested for other spiders (e.g., Cooke, 1966; Lopez, 1987). During mating, sperm uptake is necessarily supported by absorption of previous female secretions; close to oviposition, secretions probably push the sperm towards the atrium and into the fertilization ducts. A prerequisite for sperm movement by secretions are rigid spermathecal walls that preclude expansion and contraction. The thick cuticle of the internal female structures (Fig. 1B) suggests such a rigid nature. The penetration of sperm into the head regions of the spermathecae is relatively slow and continues after mating. Also, the embolus of the male is short (M.R. Simó, pers. comm.), meaning that the encapsulated and immobile sperm is initially deposited in the atrium and completely dependent on the female for transport into the receptacles. This may give the female opportunities for cryptic female choice (Eberhard, 1996). However, absorption of secretions through the head pores may also allow the male to introduce his own substances into the female system. This may determine female reluctance, as was suggested by Aisenberg \& Costa (2005) for S. malitiosa. Recently, Michalik \& Uhl (2005) identified proteinaceous male secretions accompanying the sperm in Pholcus phalangioides and suggested a potential function as substances that manipulate female receptivity. In $S$. malitiosa, female reluctance is fully developed immediately after mating (Macarena González, pers. comm.).

The dynamics of the lumen content in the atrium is poorly understood. The field of pores (with the "secondary pores") and the cross striation of the cuticle in this area indicate that glandular ducts perforate the thick atrium wall, connecting the gland cells with the atrium lumen, probably among the scale-like structures. The secretion is of unknown function, but the location suggests a role in sperm transport. The pores enter the atrium in a key site, an obligate place for sperm transit, close to both the fertilization and the copulatory ducts. Osterloh (1922) suggested a function related to nutrition of sperm, but no convincing evidence was given. Bennett (1992) stressed the importance of the potentially homologous porous plates in Dictynoidea as a phylogenetically informative character, but did not suggest a specific function. Suhm \& Alberti (1996) described a porous plate in $P$. lugubris, having similar characteristics and location to those observed in $S$. malitiosa. They suggested possible functions in activation, nutrition, or movement of sperm, but emphasized, as we also do, that the precise functions of the spermathecal glands remain unsolved.

Interestingly, some females showed asymmetry in the fluid and sperm movements inside the receptacles. In female B, sperm filled the receptacle on one side, but only a column of sperm had entered the other. One of the two $\mathrm{F}$ females, fixed just before oviposition, had only secretions in stalk and head but sperm in the atrium on one side, while sperm filled all spermathecal regions on the other side (the other female with the same treatment had sperm filling both receptacles). Asymmetry was also observed in female $\mathrm{H}$. These findings suggest either independent lateral control by the female or asymmetry in male factors, or both. Obviously, our sample size is severely limited, but the results suggest promising avenues for further research focussing on cell ultrastructure and the nature of secretions.

\section{Sperm activation and maintenance}

Sperm activation in the atrium would suggest an interesting option for sperm use by the female, because she could activate part of the sperm cells, maintaining encapsulated the remaining sperm in stalk and head. S. malitiosa females construct a mean of four egg-sacs after a single mating, during a long reproductive period (Costa \& Capocasale, 1985). In theory, females could maintain non-activated, encapsulated sperm viable for long periods (five or six months; Costa, 1991). However, we found that sperm activation is total and synchronous, possibly near the time of oviposition. Therefore, we see no evidence favouring the idea of partial sperm activation. Our data suggest for the first time that decapsulated sperm can be stored viable for a long time within the female receptacles. This long maintenance suggests a nutritive function of female secretions for stored sperm cells.

The presence of some apparently recoiled - but not recapsulated - sperm cells in female $H$ suggests that decapsulated sperm could also survive for a long time in this non-motile state, minimizing energetic costs, as suggested by Brown (1985) for the nephilid Nephila clavipes (Linnaeus, 1767) (but see Uhl, 1996). First oviposition by S. malitiosa females was observed at the end of September in the field (the beginning of spring in the southern hemisphere), and the last egg-sacs are built six months later, in March (Costa, 1991). Decapsulation could reduce the viability of sperm cells in time, and generate conditions for female remating. However, males are relatively scarce during this long egg-sac carrying period (Costa, 1991), suggesting that copulations are also scarce. The maintenance of decapsulated - and perhaps, recoiled - sperm cells may be usual during the long oviposition period.

\section{Sperm mixing versus stratification}

The sections of female E show no stratification of sperm from the two males in the right receptacle, compared to the other one that was filled by only one male, as a control. However, we cannot exclude the possibility that one of the two males did not introduce sperm into the right receptacle. In contrast, female $\mathrm{H}$ allowed us to identify the sperm of each of the two males, because the sperm cells from the first were already decapsulated while those from the second were still encapsulated. Twentyfour hours after remating, encapsulated and decapsulated sperm cells were mixed, indicating sperm mixing rather than stratification. The absence of stratification found here agrees with many findings of sperm mixing in spiders (see Elgar, 1998; Uhl, 1998, 2002; Eberhard, 2004; Huber, 2005) and deviates from the assumption that the female genital morphology is the best predictor of sperm priority patterns (Austad, 1984). However, mixing was 
not complete in the head and stalk regions, and the two types of sperm cells were distributed in a heterogeneous pattern (Fig. 4F). Our observations suggest the exciting possibility that further studies of the spatial distribution of encapsulated and decapsulated sperm cells after remating will throw light on the question of sperm stratification versus mixing.

ACKNOWLEDGEMENTS. The authors gratefully thank P. Štys and an anonymous reviewer for their critical reading of the manuscript. We would also like to specially thank M. Simo for his valuable suggestions and contributions; in addition, we acknowledge the assistance of A. Aisenberg and C. ToscanoGadea in collecting and maintaining the spiders.

\section{REFERENCES}

Aisenberg A. \& Costa F.G. 2005: Females mated without sperm transfer maintain high sexual receptivity in the wolf spider Schizocosa malitiosa. Ethology 111: 545-558.

AUSTAD S.N. 1984: Evolution of sperm priority patterns in spiders. In Smith R.L. (ed.): Sperm Competition and the Evolution of Animal Mating Systems. Academic Press, San Diego, CA, pp. 223-249.

BENNETT R.G. 1992: The spermathecal pores of spiders with special reference to dictynoids and amaurobioids (Araneae, Araneomorphae, Araneoclada). Proc. Entomol. Soc. Ont. 123: $1-21$.

Berendonck B. \& Greven H. 2005: Genital structures in the entelegyne widow spider Lactrodectus rivivensis (Arachnida; Araneae; Theridiidae) indicate a low ability for cryptic female choice by sperm manipulation. J. Morphol. 263: 118-132.

Brown S. 1985: Mating behavior of the golden-orb-weaving spider, Nephila clavipes: II. Sperm capacitation, sperm competition, and fecundity. J. Comp. Physiol. 9: 167-175.

Burger M., Nentwig W. \& Kropf C. 2003: Complex genital structures indicate cryptic female choice in a haplogyne spider (Arachnida, Araneae, Oonopidae, Gamasomorphinae). J. Morphol. 255: 80-93.

Burger M., Michalik P., Graber W., Jacob A., Nentwig W. \& KROPF C. 2006: Complex genital system of a haplogyne spider (Arachnida, Araneae, Tetrablemmidae) indicates internal fertilization and full female control over transferred sperm. J. Morphol. 267: 166-186.

Capocasale R.M., Costa F.G. \& Moreno J.C. 1984: La producción de ootecas de Lycosa malitiosa Tullgren (Araneae, Lycosidae) II. Análisis cuantitativo de hembras vírgenes y copuladas. Aracnología (Montevideo) 3: 1-7.

Cooke J.A.L. 1966: Synopsis of the structure and function of the genitalia in Dysdera crocata. Senckenberg. Biol. 47: 35-43.

Costa F.G. 1975: El comportamiento precopulatorio de Lycosa malitiosa Tullgren (Araneae, Lycosidae). Rev. Bras. Biol. 39: 359-368.

Costa F.G. 1979: Análisis de la cópula y de la actividad postcopulatoria de Lycosa malitiosa Tullgren (Araneae: Lycosidae). Rev. Bras. Biol. 39: 361-376.

Costa F.G. 1991: Fenología de Lycosa malitiosa Tullgren (Araneae, Lycosidae) como componente del criptozoos en Marindia, localidad costera del sur del Uruguay. Bol. Soc. Zool. Uruguay, 2a. época 6: 8-21.

Costa F.G. \& Capocasale R.M. 1985: La producción de ootecas de Lycosa malitiosa Tullgren (Araneae, Lycosidae) III. Distribución de las oviposiciones en el tiempo. Aracnología (Montevideo) 5: 1-14.

Coyle F.A., Harrison F.W., MacGimsey W.C. \& Palmer J.M. 1983: Observations of the structure and function of sper- mathecae in haplogyne spiders. Trans. Am. Microscop. Soc. 102: 272-280.

Eberhard W.G. 1996: Female Control: Sexual Selection by Cryptic Female Choice. Princeton University Press, New Jersey, $501 \mathrm{pp}$.

EBERHARD W.G. 2004: Why study spider sex: special traits of spiders facilitate studies of sperm competition and cryptic female choice. J. Arachnol. 32: 545-556.

Eberhard W.G. \& Huber B.A. 1998: Courtship, copulation, and sperm transfer in Leucauge mariana (Araneae, Tetragnathidae) with implications for higher classification. J. Arachnol. 26: $342-368$.

Eberhard W.G., Guzmán-Gómez S. \& Catley K.M. 1993: Correlation between spermathecal morphology and mating systems in spiders. Biol. J. Linn. Soc. 50: 197-209.

Elgar M.A. 1998: Sperm competition and sexual selection in spiders and other arachnids. In Birkhead T.R. \& Møller A.P. (eds): Sperm Competition and Sexual Selection. Academic Press, San Diego, CA, pp. 307-339.

Foelix R.F. 1996: Biology of Spiders. 2nd ed. Oxford University Press, Oxford, Georg Thieme Verlag, Berlin, $330 \mathrm{pp}$.

FORSTER R.R. 1980: Evolution of the tarsal organ, the respiratory system, and the female genitalia in spiders. In Gruber J. (ed.): Proceedings of the 8th Internationaler ArachnologenKongress. H. Egermann, Vienna, pp. 269-284.

GrasshofF M. 1968: Morphologische Kriterien als Ausdruck von Artgrenzen bei Radnetzspinnen der Subfamilie Araneinae (Arachnida: Araneae: Araneidae). Abh. Senckenberg. Naturforsch. Ges. 516: 1-100.

HARM M. 1931: Beiträge zur Kenntnis des Baues, der Funktion and der Entwicklung des akzessorischen Kopulationsorgans von Segestria bavarica C.L. Koch. Z. Morphol. Ökol. Tiere 22: 629-670

Hickman V.V. 1975: On Paraplectanoides crassipes Keyserling (Araneae: Araneidae). Bull. Br. Arachnol. Soc. 3: 166-174.

HigGINS L.E. 1989: Effect of insemination on the morphology of the internal female genitalia of the spider Nephila clavipes. (Araneae: Araneidae). Ann. Entomol. Soc. Am. 82: 748-753.

Huber B.A. 1994: Copulatory mechanics in the funnel-web spiders Histopona torpida and Textrix denticulata (Agelenidae, Araneae). Acta Zool. (Stockholm) 75: 379-384.

Huber B.A. 1995a: Genital morphology and copulatory mechanics in Anyphaena accentuata (Anyphaenidae) and Clubiona pallidula (Clubionidae: Araneae). J. Zool. 235: 689-702.

HUBER B.A. 1995b: Genital morphology, copulatory mechanism and reproductive biology in Psilochorus simoni (Berland, 1911) (Pholcidae; Araneae). Neth. J. Zool. 44: 85-99.

Huber B.A. 1998: Genital mechanics in some Neotropical pholcid spiders (Araneae: Pholcidae), with implications for systematics. J. Zool. 244: 587-599.

HUBER B.A. 2005: Sexual selection research in spiders: progress and biases. Biol. Rev. 80: 363-385.

JÄRVI T.H. 1908: Über die Vaginalsysteme der Lycosiden Thor. Zool. Anz. 32: 754-758.

Kovoor J. 1981: Une source probable de phéromones sexuelles: les glandes tégumentaires de la région génitale des femelles d'araignées. Atti Soc. Toscana Sci. Nat. Mem. 88: 1-15.

LAMORAL B.H. 1973: On the morphology, anatomy, histology and function of the tarsal organ on the pedipalpi of Palystes castaneus (Sparassidae, Araneidae). Ann. Natal Mus. 21: 609-648.

LOPEZ A. 1987: Glandular aspects of sexual biology. In Nentwig W. (ed.): Ecophysiology of Spiders. Springer Verlag, Berlin pp. 121-132. 
LoPez A. \& Juberthie-JupeAu L. 1983: Structure et ultrastructure de la spermathèque chez Telema tenella Simon (Araneae, Telemidae). Mém. Biospéol. 10: 413-418.

Michalik P. \& Uhl G. 2005: The male genital system of the cellar spider Pholcus phalangioides (Fuesslin, 1775) (Pholcidae, Araneae): development of spermatozoa and seminal secretion. Front. Zool. 2: 12

Michalik P., Reiher W., Tintelnoth-Suhm M., Coyle F.A. \& Alberti G. 2005: Female genital system of the foldingtrapdoor spider Antrodiaetus unicolor (Hentz, 1842) (Antrodiaetidae, Araneae): ultrastructural study of form and function with notes on reproductive biology of spiders. J. Morphol. 263: 284-309.

Osterloh A. 1922: Beiträge zur Kenntnis des Kopulationsapparates einiger Spinnen. Z. Wiss. Zool. 119: 326-421.

RovNeR J.S. \& Wright E.E. 1975: Copulation in spiders: experimental evidence for fatigue effects and bilateral control of palpal insertions. Anim. Behav. 23: 233-236.

SADANA G.L. 1972: Mechanics of copulation in Lycosa chaperi Simon (Araneida: Lycosidae). Bull. Br. Arach. Soc. 2: 87-89.

Serna DE Esteban C.J.D.L. 1976: Algunas observaciones anatomo-histologicas sobre el aparato reproductor de la hembra de Ariadna mollis (Holmberg, 1876) (Araneae, Labidognatha, Haplogynae). Physis (Buenos Aires) (Sec. C) 35: 139-146.

SIERWALd P. 1989: Morphology and ontogeny of female copulatory organs in American Pisauridae, with special reference to homologous features (Arachnida: Araneae). Smiths. Contrib. Zool. 484: 1-24.
Suhm M. \& Alberti G. 1996: The fine structure of the spermatheca of Pardosa lugubris (Walckenaer, 1802). Rev. Suisse Zool. Vol. Hors Série 2: 635-642.

UHL G. 1993a: Sperm storage and repeated egg production in female Pholcus phalangioides Fuesslin (Araneae). Bull. Soc. Neuchat. Sci. Nat. 116: 245-252.

UHL G. 1993b: Mating behaviour and female sperm storage in Pholcus phalangioides (Fuesslin) (Araneae). Mem. Qd Mus. 33: 667-674.

UhL G. 1994: Genital morphology and sperm storage in Pholcus phalangioides (Fuesslin, 1775) (Pholcidae; Araneae). Acta Zool. (Stockholm) 75: 1-12.

UhL G. 1996: Sperm storage secretion of the female cellar spiders (Pholcus phalangioides; Araneae): a gel-electrophoretic analysis. J. Zool. 240: 153-161.

UhL G. 1998: Mating behaviour in the cellar spider, Pholcus phalangioides, indicates sperm mixing. Anim. Behav. 56: 1155-1159.

UHL G. 2000: Two distinctly different sperm storage organs in female Dysdera erythrina (Araneae: Dysderidae). Arthr. Struct. Devel. 29: 163-169.

UHL G. 2002: Female genital morphology and sperm priority patterns in spiders (Araneae). In Toft S. \& Scharff N. (eds): European Arachnology 2000. 19th European Colloquium of Arachnology, Aarhus, Denmark, 17-22 July 2000. Aarhus University Press, Aarhus, pp. 145-156.

Van Helsdingen P.J. 1970: A reclassification of the species of Linyphia based on the functioning of the genitalia (Araneida, Linyphiidae). Part II. Microlinyphia Gerhardt and Frontinellina van Helsdingen. Zool. Verh. 111: 1-86.

Received January 23, 2007; revised and accepted April 23, 2007 